\title{
IDŐJÁRÁS
}

Quarterly Journal of the Hungarian Meteorological Service

Vol. 125, No. 2, April-June, 2021, pp. 229-253

\section{Spatiotemporal variability of air temperatures in Central Serbia from 1949 to 2018}

\author{
Nikola R. Bačević ${ }^{* 1}$, Nikola M. Milentijević ${ }^{1}$, Aleksandar Valjarević ${ }^{2}$, \\ Ajša Gicić ${ }^{1}$, Dušan Kićović ${ }^{3}$, Milica G. Radaković ${ }^{4}$, Milena Nikolić ${ }^{1}$, \\ and Milana Pantelić ${ }^{4}$
}

\author{
${ }^{1}$ University of Priština, Faculty of Sciences \\ Department of Geography \\ Kosovska Mitrovica, Serbia \\ ${ }^{2}$ University of Belgrade, Faculty of Geography \\ Studentski Trg 3/III, Belgrade, Serbia \\ ${ }^{3}$ The College of Tourism \\ Academy of Applied Studies, Belgrade, Serbia \\ ${ }^{4}$ University of Novi Sad, \\ Faculty of Sciences, Department of Geography, \\ Tourism and Hotel Management, Novi Sad, Serbia \\ *Corresponding author e-mail: nikola.bacevic@pr.ac.rs
}

(Manuscript received in final form July6, 2020)

\begin{abstract}
The paper presents trends for three categories of variables: average annual, average maximum and average minimum air temperatures. Data was provided by the meteorological yearbooks of the Republic Hydrometeorological Service of Serbia. The main goal of this paper is to detect possible temperature trends in Central Serbia. The trend equation, trend magnitude, and Mann-Kendall non-parametric test were used in the analysis of climate parameters. The used statistical methods were supplemented by GIS numerical analysis, which aimed to analyze the spatial distribution of isotherms from 1949 to 2018 . The obtained results indicate that out of the 72 analyzed time series, an increase in air temperature is dominant in 61 time series, while 11 time series show no changes. The highest increase was recorded in the average maximum time series $\left(4.2^{\circ} \mathrm{C}\right.$ ), followed by an increase of $3.5^{\circ} \mathrm{C}$ in average maximum air temperatures. The highest increase in the average annual time-series was $3.0^{\circ} \mathrm{C}$. The lowest increases in air temperature were recorded in the average minimum time series $\left(0.1\right.$ and $\left.0.2^{\circ} \mathrm{C}\right)$. In two average minimum time series a decrease in average air temperatures was identified (-0.6 and $-0.4{ }^{\circ} \mathrm{C}$. The application of GIS tools indicates the existence of interregional
\end{abstract}


differences in the arrangement of isotherms, leaded by the orography of the terrain. In the spatial distribution of the analyzed variables, "poles of heat" and "poles of cold" stand out, and the influence of the urban heat island is evident (especially in the case of the urban agglomeration of Belgrade). The manifested spatial patterns of air temperature need to be further examined and the correlation with possible causes need to be determined. For these reasons, the paper provides a solid basis for studying the climate of this area in the future, as it provides insight into climate dynamics over the past decades.

Key-words: variability, climate change, air temperature trends, Mann-Kendall trend test, GIS numerical analysis, isotherms, Central Serbia

\section{Introduction}

Climate change is referred to as large variations in climate averages which exist for decades or even longer periods. Hansen et al. (2013) concluded that the Pleistocene climate oscillations yield a fast-feedback climate sensitivity of $3 \pm 1{ }^{\circ} \mathrm{C}$ for a $4 \mathrm{~W} \mathrm{~m}^{-2} \mathrm{CO}_{2}$ forcing if Holocene warming relative to the Last Glacial Maximum (LGM) is used as calibration. The most of the research on climate change and climate variability was focused on analyses of the second half of the 20th century. This is highlighted by the conclusion of the 5th Assessment Report (AR5) of the Intergovernmental Panel on Climate Change (IPCC): ,it is extremely likely that more than half of the observed increase in global average surface temperature from 1951 to 2010 was caused by the anthropogenic increase in greenhouse gas concentrations and other anthropogenic forcings together" (Bindoff et al., 2013). According to the IPCC (2018), a $0.87^{\circ} \mathrm{C}$ increase of mean air temperature on global scale during the last decade (2005-2015) was identified. A similar trend continued during this decade. Thus, the WMO (2019) identified 2015, 2016, 2017, and 2018 as the warmest years during the instrumental period.

In recent years, various studies for detecting possible trends and changes related to climate across the world's regions have been published. Klein Tank and Können (2003) identified changes in mean air temperatures trends for more than 100 meteorological stations across Europe. The pronounced warming was especially intensive between 1976 and 1999; it is primarily associated with an increase in warm extremes rather than with a decrease in cold extremes. ElNesr et al. (2010) analyzed the changes of air temperature trends over the Arabian Peninsula. A warming trend was found in cases of mean annual, mean maximum, and mean minimum air temperatures. Exceptions are the winter months (November to January), where non-significant cooling trends were observed. Karaburun et al. (2011) analyzed the trends of annual, seasonal, and monthly mean, minimum, and maximum temperatures in Istanbul from 1975 to 2006 by using the Mann-Kendall (MK) test and the Sen's method. Based on the air temperature measurements from 622 meteorological stations in China, Du et al. (2019) analyzed the temperature response to the global warming effects at 
national and regional scales. They identified air temperature changes from $0.2^{\circ} \mathrm{C}$ per decade from 1998 to 2012 . However, the mean increase is lower in comparison to the period from 1960 to $1998\left(0.4^{\circ} \mathrm{C}\right.$ per decade $)$.

Numerous papers are dealing with air temperature changes across the regions of Southeast Europe: in Montenegro (Luković et al., 2013; Burić et al., 2014, 2015, 2018, 2019), Bosnia and Herzegovina (Trbić et al., 2017; Popov et al., 2017, 2018a, 2018b, 2019), Croatia (Tadić et al., 2019; Radilović et al., 2020), and Slovenia (Milošević et al., 2013, 2017; Tošić et al., 2016).

Observed climatological data for Serbia were analyzed and classified into a few main categories: air temperature variables (Unkašević and Tošić, 2013; Gocić and Trajković, 2013; Bajat et al., 2015; Putniković et al., 2018; Vukoičić et al., 2018) and parameters as aridity and drought (Gocić and Trajković, 2014a, 2014b; Hrnjak et al., 2014; Radaković et al., 2018; Milentijević et al., 2018; Trajković et al., 2020). Several papers are focused on climate change problems on regional level on the territory of Serbia: Vojvodina (Gavrilov et al., 2015, 2016, 2019), Kosovo and Metohija ${ }^{1}$ (Bačević et al., 2017, 2018; Gavrilov et al., 2018). However, on the territory of Central Serbia, air surface temperature trends were not examined up to now. For that reason, the purpose of this paper is to analyze the variability of selected meteorological variables at 24 meteorological stations over Central Serbia from 1949 to 2018. Thus, the main objectives of this study are: (1) to analyze and discuss the trend characteristics of meteorological variables in details; (2) to quantify the significance of changes by using the linear regression, the trend magnitude calculated from the trend equation, and by the application of MK non-parametric test; and (3) to present spatial distribution of isotherms on a defined study area using GIS numerical analysis.

\section{Data and methods}

\subsection{Research area}

Central Serbia is located on the Balkan Peninsula and is a toponym that refers to the territory of Serbia (excluding the autonomous provinces Vojvodina, and Kosovo and Metohija). The borders of Central Serbia with the neighboring regions are natural: 1) in the west the River Drina forms the border with Bosnia and Herzegovina, 2) in the north, the River Danube forms the border with Romania, while Danube and Sava rivers with Vojvodina, 3) in the east, the Carpatho-Balkans form the border with Bulgaria, 4) in the south it borders Northern Macedonia, and 5) in the southwest it borders Montenegro. The total

\footnotetext{
${ }^{1}$ According to the Kumanovo Agreement and United Nations Security Council Resolution 1244 (1999), Kosovo and Metohija are considered as the part of Serbian territory under the international protectorate (Clark, 2014).
} 
area of Central Serbia (Fig. 1) is $55,947 \mathrm{~km}^{2}$, and it makes up $63.3 \%$ of the territory of the Republic of Serbia $\left(88,361 \mathrm{~km}^{2}\right)$. The most important orographic units that affect the transformation of air masses and the climate of Central Serbia are the Pannonian Plain, the Dinarides, and the Carpatho-Balkans. Arctic continental air masses come to Central Serbia across the Pannonian Plain in the colder half of the year. The Dinarides and Carpatho-Balkanids represent an orographic barrier, which weakens the flow of air masses. In these parts, continental tropical air masses originating from North Africa in the warmer half of the year cause high summer temperatures (Ducić and Radovanović, 2005). As a consequence of this atmospheric circulation, absolute temperature extremes were recorded in the meteorological stations of Serbia. Thus, in Smederevska Palanka, the absolute maximum air temperature of $44.9^{\circ} \mathrm{C}$ was recorded on July 24, 2007. The absolute temperature minimum of $-39.0^{\circ} \mathrm{C}$ was recorded on the Pešter plateau, on January 26, 2006 (Andjelković, 2007). In Central Serbia, the influence of the continental and temperate-continental climates prevail. According to the Köppen climate classification, Central Serbia belongs to the Cfa climate (average temperature above $20^{\circ} \mathrm{C}$ during the warmer months and above $-3{ }^{\circ} \mathrm{C}$ during the colder months), while in the high mountains (above $1500 \mathrm{~m}$ ) the Dfa climate is present (average temperature below $20^{\circ} \mathrm{C}$ during warmer months and below $-3{ }^{\circ} \mathrm{C}$ during colder months (Radinović, 1981). The average annual air temperature for the time interval from 1949 to 2018 is $10.7^{\circ} \mathrm{C}$, the average maximum air temperature is $25^{\circ} \mathrm{C}$, while the average minimum temperature is $-1.9^{\circ} \mathrm{C}$.

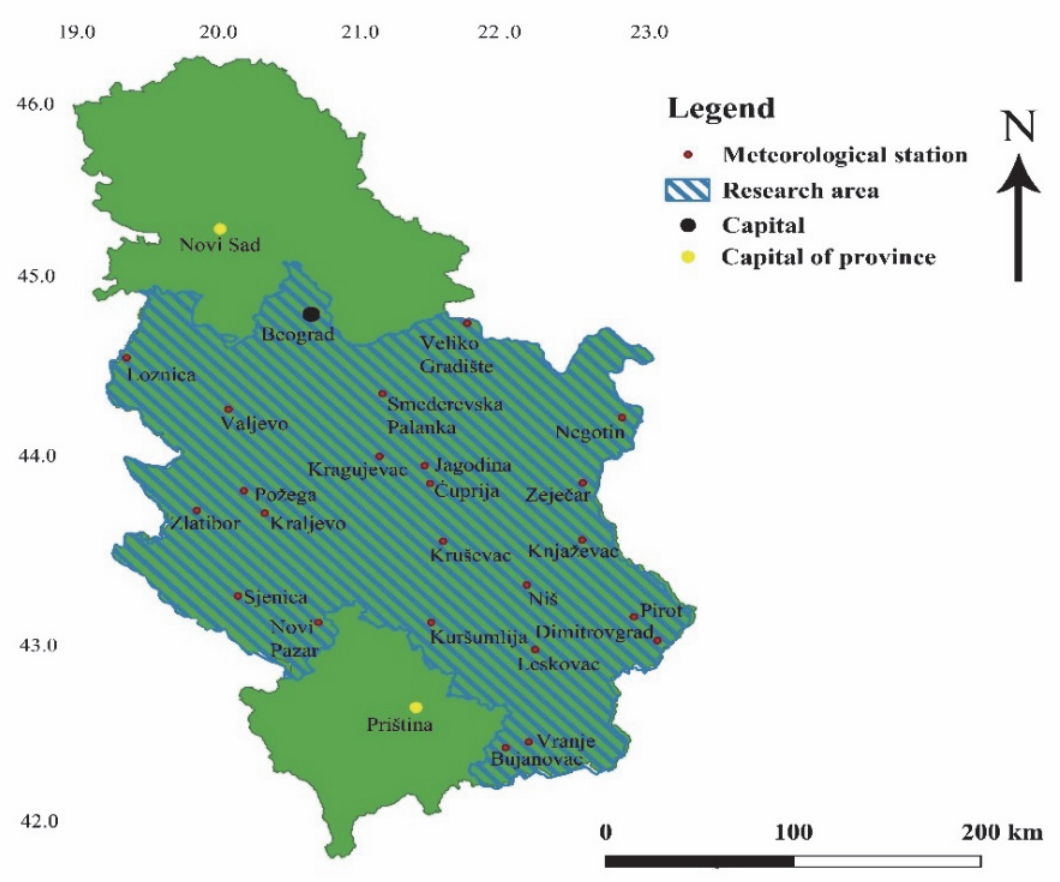

Fig. 1. Geographical position of Central Serbia with the analyzed meteorological stations. 


\subsection{Materials}

In this study, three data sets of surface air temperatures were used: monthly mean temperatures, monthly maximum temperatures, and monthly minimum temperatures. From these three data sets, new data sets were created: mean annual air temperatures $(Y T)$, mean maximum air temperatures $\left(Y T_{x}\right)$, and mean minimum air temperatures $\left(Y T_{n}\right)$. The selected climatological datasets were collected from 24 meteorological stations from Central Serbia for the period from 1949 to 2018. For the purpose of this study, based on the mentioned meteorological stations, 72 time series were identified (Fig. 2). The data (Table 1) were obtained from the Republic Hydrometeorological Service of Serbia (RHSS, 2019). Analysis was performed on the selected stations due to three reasons: 1) each of the stations has good quality of datasets, 2) the data are reliable, 3) the data have adequate record length. Before calculation, the homogeneity of the temperature data was examined. Inhomogeneity in time series can cause the incorrect interpretation of climate time series (Rahman et al., 2017), and be misleading in the interpretation of tendencies in the time series. Several methods can be used to detect abrupt changes, e.g., Alexandersson's test (Alexandersson, 1986), Pettitt's test (Kocsis et al., 2020). In this paper, the homogeneity test according to Alexandersson (1986) was performed. Applying the Alexandersson's test, all series were found to be homogeneous. Heterogenity of orography indicates different climate conditions over the defined study area. For example, the relative altitude between the highest (Sjenica) and the lowest meteorological stations (Negotin) is 996 meters of altitude.

\subsection{Methods}

Three main statistical procedures were used in order to analyze the temperature trends in 72 time series. In the first step, the trend equation (tendency) was calculated for each time series using the method of linear regression (Mudelsee, 2014). Second, in all cases the trend magnitude was calculated from the trend equation (Gavrilov et al., 2018). Finally, the third step was to asses all trends using the MK non-parametric test (Zeleňáková et al., 2018). 
Table 1. Geographic features and short names of the analyzed meteorological stations used in the study.

\begin{tabular}{clccc}
\hline \hline Station No. & Station name & Latitude (N) & Longitude (E) & Altitude (m) \\
\hline \hline 1. & Beograd (BG) & $44^{\circ} 48^{\prime}$ & $20^{\circ} 28^{\prime}$ & 132 \\
2. & Bujanovac (BU) & $42^{\circ} 27^{\prime}$ & $21^{\circ} 46^{\prime}$ & 399 \\
3. & Ćuprija (CU) & $43^{\circ} 56^{\prime}$ & $21^{\circ} 23^{\prime}$ & 123 \\
4. & Dimitrovgrad (DI) & $43^{\circ} 01^{\prime}$ & $22^{\circ} 45^{\prime}$ & 450 \\
5. & Jagodina (JA) & $43^{\circ} 59^{\prime}$ & $21^{\circ} 23^{\prime}$ & 115 \\
6. & Knjaževac (KŽ) & $43^{\circ} 34^{\prime}$ & $22^{\circ} 15^{\prime}$ & 263 \\
7. & Kragujevac (KG) & $44^{\circ} 02^{\prime}$ & $20^{\circ} 56^{\prime}$ & 181 \\
8. & Kraljevo (KV) & $43^{\circ} 43^{\prime}$ & $20^{\circ} 42^{\prime}$ & 215 \\
9. & Kruševac (KS) & $43^{\circ} 37^{\prime}$ & $21^{\circ} 15^{\prime}$ & 404 \\
10. & Kuršumlija (KU) & $43^{\circ} 08^{\prime}$ & $21^{\circ} 16^{\prime}$ & 384 \\
11. & Leskovac (LE) & $42^{\circ} 59^{\prime}$ & $21^{\circ} 57^{\prime}$ & 231 \\
12. & Loznica (LO) & $44^{\circ} 32^{\prime}$ & $19^{\circ} 14^{\prime}$ & 121 \\
13. & Negotin NG) & $44^{\circ} 14^{\prime}$ & $22^{\circ} 32^{\prime}$ & 42 \\
14. & Niš (NI) & $43^{\circ} 20^{\prime}$ & $21^{\circ} 54^{\prime}$ & 202 \\
15. & Novi Pazar (NP) & $43^{\circ} 08^{\prime}$ & $20^{\circ} 31^{\prime}$ & 545 \\
16. & Pirot (PI) & $43^{\circ} 09^{\prime}$ & $22^{\circ} 35^{\prime}$ & 373 \\
17. & Požega (PŽ) & $43^{\circ} 51^{\prime}$ & $20^{\circ} 02^{\prime}$ & 311 \\
18. & Sjenica (SJ) & $43^{\circ} 16^{\prime}$ & $20^{\circ} 00^{\prime}$ & 1038 \\
19. & Smederevska Palanka (SP) & $44^{\circ} 22^{\prime}$ & $20^{\circ} 57^{\prime}$ & 121 \\
20. & Valjevo (VA) & $44^{\circ} 17^{\prime}$ & $19^{\circ} 55^{\prime}$ & 174 \\
21. & Veliko Gradište (VG) & $44^{\circ} 45^{\prime}$ & $21^{\circ} 30^{\prime}$ & 8029 \\
22. & Vranje (VR) & $42^{\circ} 33^{\prime}$ & $21^{\circ} 55^{\prime}$ & $22^{\prime}$ \\
23. & Zaječar (ZA) & $43^{\circ} 53^{\prime}$ & $19^{\circ} 43^{\prime}$ & \\
24. & Zlatibor (ZL) & $43^{\circ} 44^{\prime}$ & & \\
\hline & & & & \\
\hline
\end{tabular}

\subsubsection{Linear regression and trend equation}

The linear regression describes $X_{\text {trend }}$ by means of two parameters, namely the intercept, $\beta_{0}$, and the slope, $\beta_{1}$ (Mudelsee, 2019). This method is used to estimate the trend by the following equation:

$$
X(i)=\beta_{0}+\beta_{1} T(i)+S(i) X_{\text {noise }}(i),
$$

where $T(i)$ is the time variable assigned to $X(i)$ and $S(i) X_{\text {noise }}(i)$ is the error term. 
The trend equation has been long utilized in this type of research as an approach (Wibig and Glowicki, 2002), because it gives results which are simple to interpret; both graphically and analytically on the basis of the shape and parameters of the trend equation. For instance, the sign of the temperature trend depends on the value of the slope. There are three possible scenarios: a) if the size of slope is greater than zero, the sign of trend is positive (increase); b) if it is equal to zero, there is no trend (no changes); and c) if it is less than zero, the sign of trend is negative (decrease).

\subsubsection{The trend magnitude}

Based on the trend equation, the trend magnitude was defined and calculated as the difference in air surface temperature between the beginning and the end of the period (Gavrilov et al., 2016). The explained statistical procedure was defined as:

$$
\Delta y=y\left(P_{b}\right)-y\left(P_{e}\right),
$$

where $\Delta y$ is the trend magnitude in ${ }^{\circ} \mathrm{C}$, values $y\left(P_{b}\right)$ and $y\left(P_{e}\right)$ represent air surface temperatures from the trend equation in the beginning, $P b$, and at the end of period, $P e$. In our cases, the beginning period is defined as, $P_{b}=1949$, while the end of the period is $P e=2018$.

\subsubsection{The Mann-Kendall non-parametric test}

In this study, the non-parametric MK test is used for the detection of the trend in a time series. This test is widely used in environmental science, because it is simple and robust and can cope with missing values and values below a detection limit. The first proposal of the test was by Mann (1945) and Kendall (1938). The MK test is a rank-based nonparametric test for assessing the significance of a trend, and it has been widely used in hydrometeorological trend detection studies: hydrological time series (Burn and Hag Elnur, 2002); air surface temperature (Karmeshu, 2012), precipitation (Ahmad et al., 2015), temperature extremes (Serra et al., 2001), aridity (Hrnjak et al., 2014), evapotranspiration (Shadmani et al., 2012). However, inconsistencies in hydroclimatical data recording may occur due to various reasons, such as: instrumentation, changes in observation procedures, or changes in gauge location or surrounding conditions (Alexander et al., 2006).

The MK test statistic $S$ (Karmeshu, 2012) can be calculated as:

$$
S=\sum_{i=1}^{n-1} \sum_{j=i+1}^{n} \operatorname{sgn}\left(x_{j}-x_{i}\right),
$$


where $n$ is the number of data points, $x_{j}$ and $x_{i}$ are the data values in time series $i$ and $j(j>i)$, respectively, and $\operatorname{sgn}\left(x_{j}-x_{i}\right)$ is the sign function as:

$$
\operatorname{sgn}\left(x_{j}-x_{i}\right)=\left\{\begin{array}{clc}
+1, & \text { if } & x_{j}-x_{i}>0 \\
0, & \text { if } & x_{j}-x_{i}=0 \\
-1, & \text { if } & x_{j}-x_{i}<0
\end{array}\right\}
$$

The variance is computed as:

$$
\operatorname{var}(S)=\frac{n(n-1)(2 n+5)-\sum_{i=1}^{m} t_{i}\left(t_{i}-1\right)\left(2 t_{i}+5\right)}{18},
$$

where $n$ is the number of data points, $m$ represents the number of tied groups while $t_{i}$ denotes the number of ties of extent $i$. A tied group is a set of sample data having the same value. In cases where the sample size $n>10$, the standard normal test statistic $Z_{s}$ is computed as:

$$
Z_{S}=\left\{\begin{array}{cll}
\frac{s-1}{\sqrt{\operatorname{var}(S)}}, & \text { if } & S>0 \\
0, & \text { if } & S=0 \\
\frac{s+1}{\sqrt{\operatorname{var}(S)}} & \text { if } & S<0
\end{array}\right\},
$$

Positive values of $Z_{s}$ indicate increasing trends, while negative $Z_{s}$ values show decreasing trends. Testing trends is done at the specific $\alpha$ significance level. By using MK test, two hypotheses were tested: zero hypothesis $\left(H_{0}\right)-$ pointing to the inexistence of trend in time series; and alternative hypothesis $\left(H_{a}\right)$ - pointing to the existence of statistically significant trend in time series for the chosen level of significance $(\alpha)$. The main role in MK test belongs to the value of $p$ (Razavi et al., 2016). The value of $p$ determines the accuracy of hypothesis. If the value $p$ is lower than the chosen level of significance $\alpha$ (it is common that $\alpha=0.05$ or $5 \%$ ), the hypothesis $H_{0}$ should be rejected and hypothesis $H_{a}$ is accepted. When $p$ is larger than the level of significance, then the hypothesis $\mathrm{H}_{0}$ is accepted (Gavrilov et al., 2016). In the paper XLSTAT software was used (www.xlstat.com) for calculating the probability $p$, and for hypothesis testing.

\subsubsection{QGIS analysis}

GIS and data modeling are very powerful tools for estimating and calculating data of meteorological properties within an area (Tomazos and Butler, 2009; Blake et al., 2007). There are several methods for this calculation, but in this 
research we gave importance to the methods of kriging and interpolations. Semi-automated and ordinary kriging methods were established trough the QGIS 3.12.0 (Quantum Geographical Information System) and SAGA (System for Automated Geoscientific Analysis) tools. Although there are a few other methods which can be used in spatial analysis, the priority is given to the semiautomated and ordinary krigings, because they include autocorrelation of the statistical relationship among measured points (Valjarević et al., 2018). These maps show the dispersion of climate properties, temperature and precipitation on the territory of Central Serbia. GIS methods and spatial variability functions can be used along with methods of interpolation in mapping the climate properties (Wang et al., 2018). The models used in the spatial research are based on the Gaussian distribution. QGIS has a wide range of spatial models, which can be successfully applied. Method of interpolation is also used in order to compare potential errors in the estimations. In this research, the data from 24 meteorological stations were used. These stations are well distributed. In that way, the created maps have a small percent of errors.

\section{Results}

\subsection{Trend parameters}

In this paper, the main results are summarized in Table 2 and Figs. 2 and 3. The data for 24 meteorological stations, which are located in Central Serbia (a total of 72 time series), are analyzed. The obtained results for the analyzed climate variables are presented through the trend equation and trend magnitude in Fig. 2 and Table 2. The results of the MK trend test as well as the evaluation of hypotheses are shown in Fig. 3. The spatial distribution of average annual (YT), average maximum $\left(Y T_{x}\right)$, and average minimum $\left(Y T_{n}\right)$ air temperatures is shown in more detail in Fig. 4. 

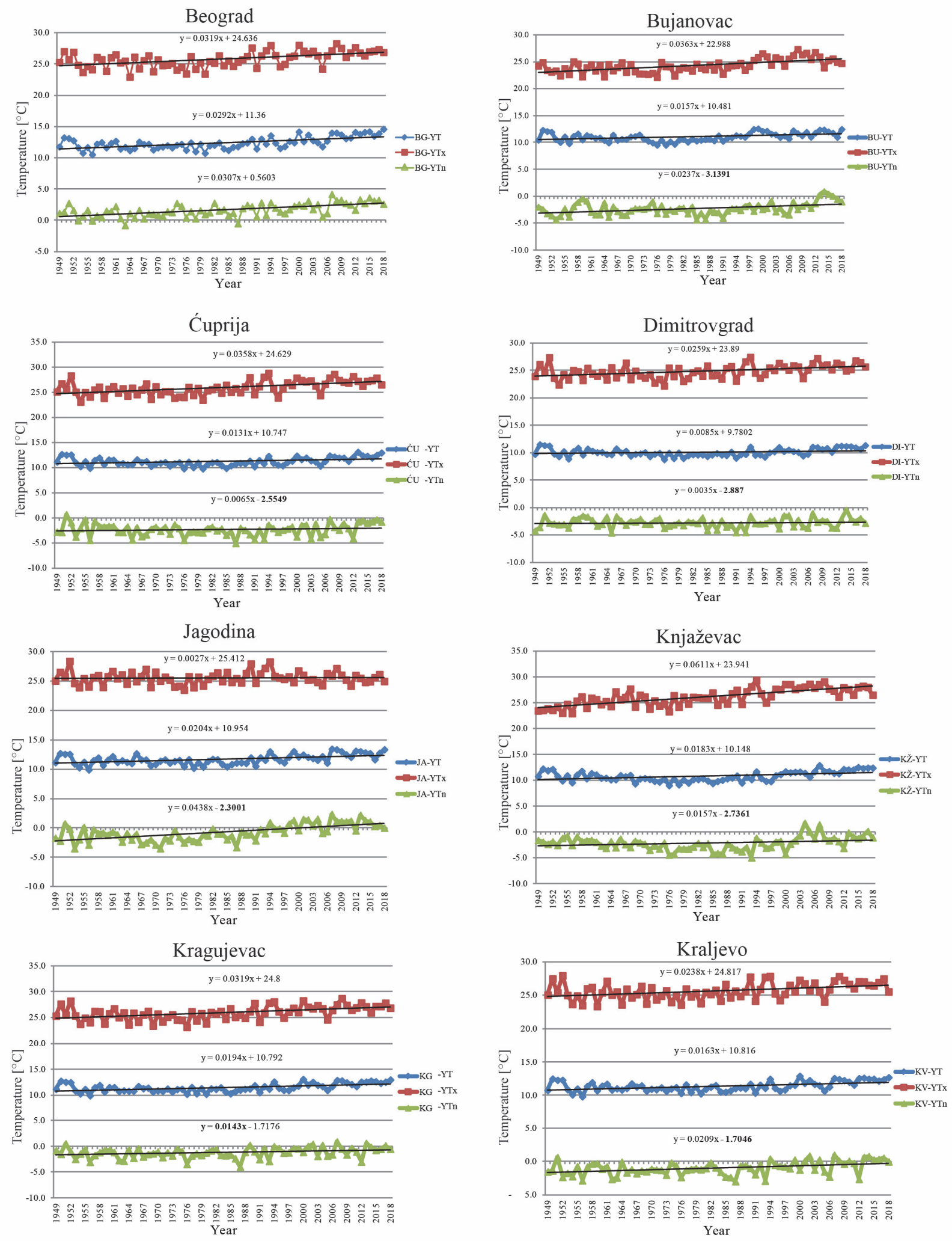

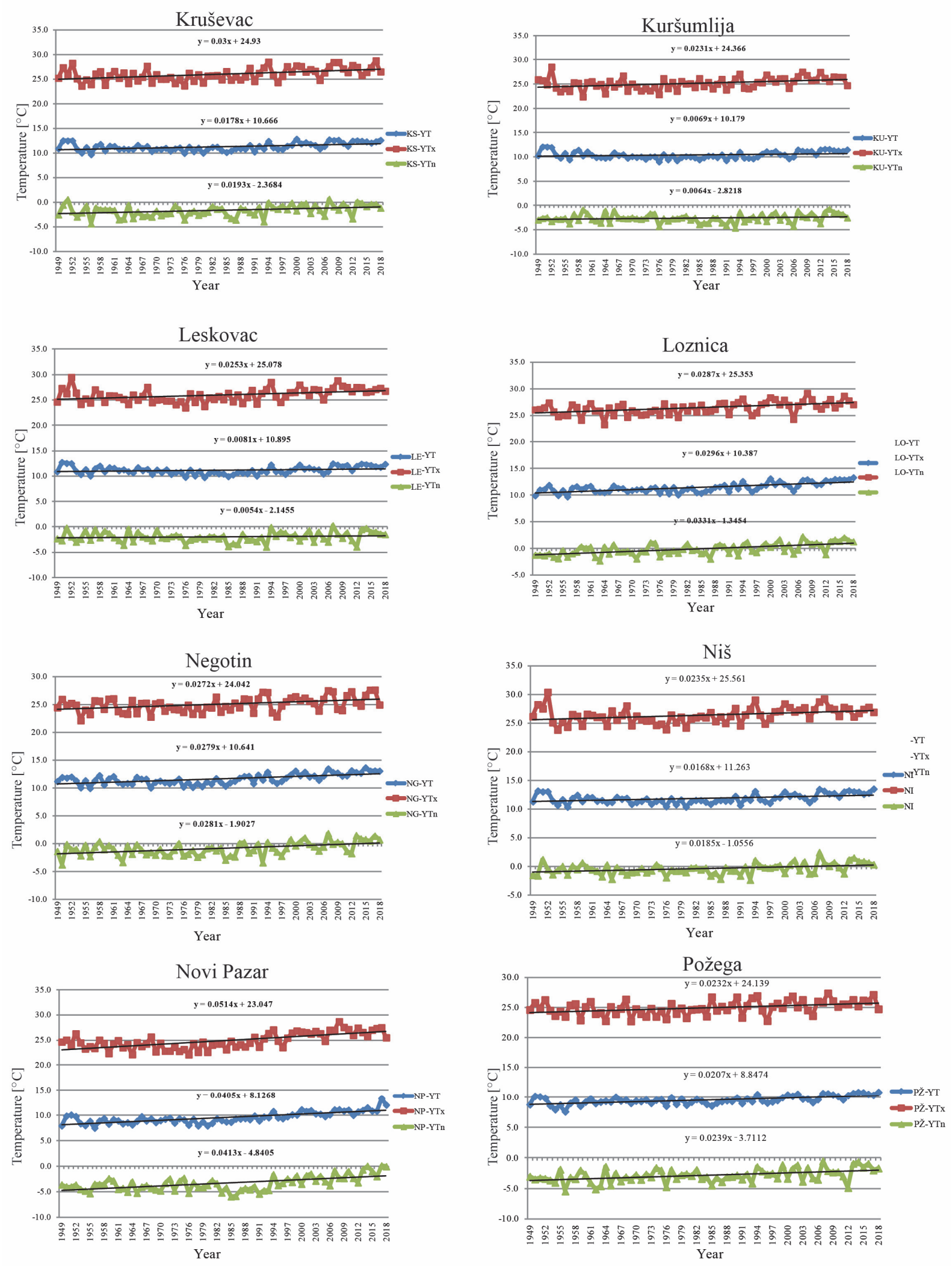

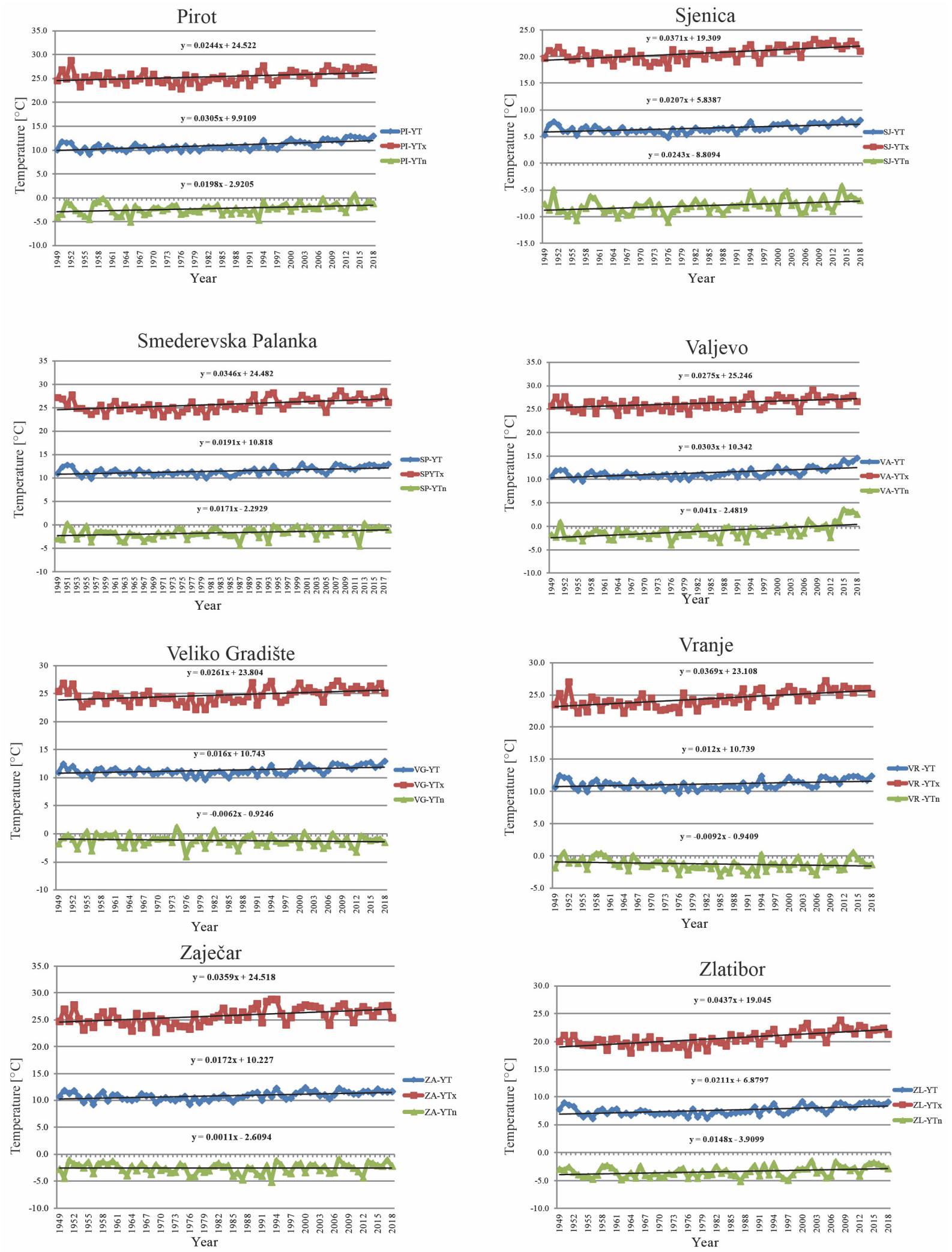

Fig. 2. Average annual (YT), average maximum $\left(\mathrm{YT}_{\mathrm{x}}\right)$ and average minimum air temperatures $\left(\mathrm{YT}_{\mathrm{n}}\right)$, trend equations and linear trend for selected meteorological stations in Central Serbia from 1949 to 2018. 
Table 2. Trend equation, trend magnitude $(\Delta y)$, and average temperature for 72 time series for average annual $(Y T)$, average maximum $\left(Y T_{x}\right)$ and average minimum $\left(Y T_{n}\right)$ temperatures for the 24 selected stations. Acronyms for stations are listed in Fig. 2.

\begin{tabular}{|c|c|c|c|}
\hline Time series & Trend equation & $\Delta y\left({ }^{\circ} \mathrm{C}\right)$ & Average temperature $\left({ }^{\circ} \mathrm{C}\right)$ \\
\hline BG-YT & $y=0.0292 x+11.36$ & 2.0 & 12.1 \\
\hline$B G-Y_{x}$ & $y=0.0319 x+24.636$ & 2.2 & 25.8 \\
\hline$B G-Y T_{n}$ & $y=0.0307 x+0.5603$ & 2.1 & 1.6 \\
\hline BU-YT & $y=0.0157 x+10.481$ & 1.1 & 11.0 \\
\hline$B U-\mathrm{YT}_{\mathrm{x}}$ & $y=0.0363 x+22.988$ & 2.5 & 24.3 \\
\hline$B U-Y T_{n}$ & $y=0.0237 x-3.1391$ & 1.6 & -2.3 \\
\hline ĆU-YT & $y=0.0131 x+10.747$ & 0.9 & 11.2 \\
\hline ĆU-YT ${ }_{x}$ & $y=0.0358 x+24.629$ & 2.5 & 25.9 \\
\hline ĆU-YT ${ }_{\mathrm{n}}$ & $y=0.0065 x-2.5549$ & 0.5 & -2.3 \\
\hline DI-YT & $y=0.0085 x+9.7802$ & 0.6 & 10.1 \\
\hline DI-YT $T_{x}$ & $y=0.0259 x+23.89$ & 1.8 & 24.8 \\
\hline DI-YT $T_{n}$ & $y=0.0035 x-2.887$ & 0.2 & -2.8 \\
\hline JA-YT & $y=0.0204 x+10.954$ & 1.4 & 11.7 \\
\hline $\mathrm{JA}-\mathrm{YT}_{\mathrm{x}}$ & $y=0.0027 x+25.412$ & 0.2 & 25.5 \\
\hline$J A-Y_{n}$ & $y=0.0438 x-2.3001$ & 3.0 & -0.7 \\
\hline KŽ-YT & $y=0.0183 x+10.148$ & 1.3 & 10.8 \\
\hline 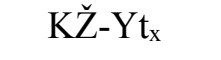 & $y=0.0611 x+23.941$ & 4.2 & 26.1 \\
\hline $\mathrm{KŽ}-\mathrm{YT}_{\mathrm{n}}$ & $y=0.0157 x-2.7361$ & 1.1 & -2.2 \\
\hline KG-YT & $y=0.0194 x+10.792$ & 1.3 & 11.5 \\
\hline $\mathrm{KG}-\mathrm{YT}_{\mathrm{x}}$ & $\mathrm{y}=0.0319 x+24.8$ & 2.2 & 25.9 \\
\hline$K G-Y_{n}$ & $y=0.0143 x-1.7176$ & 1.0 & -1.2 \\
\hline KV-YT & $y=0.0319 x+24.8$ & 1.1 & 11.4 \\
\hline $\mathrm{KV}-\mathrm{YT}_{\mathrm{x}}$ & $y=0.0319 x+24.8$ & 1.6 & 25.6 \\
\hline $\mathrm{KV}-\mathrm{YT}_{\mathrm{n}}$ & $\mathrm{y}=0.0319 x+24.8$ & 1.4 & -1.0 \\
\hline KS-YT & $y=0.0178 x+10.666$ & 1.2 & 11.3 \\
\hline $\mathrm{KS}-\mathrm{YT}_{\mathrm{x}}$ & $y=0.03 x+24.93$ & 2.1 & 26.0 \\
\hline $\mathrm{KS}-\mathrm{YT}_{\mathrm{n}}$ & $y=0.0193 x-2.3684$ & 1.3 & -1.7 \\
\hline KU-YT & $y=0.0069 x+10.179$ & 0.5 & 10.4 \\
\hline $\mathrm{KU}-\mathrm{YT}_{\mathrm{x}}$ & $y=0.0231 x+24.366$ & 1.6 & 25.2 \\
\hline $\mathrm{KU}-\mathrm{YT}_{\mathrm{n}}$ & $y=0.0064 x-2.8218$ & 0.4 & -2.6 \\
\hline LE-YT & $y=0.0081 x+10.895$ & 0.6 & 11.2 \\
\hline $\mathrm{LE} \mathrm{YT}_{\mathrm{x}}$ & $y=0.0253 x+25.078$ & 1.7 & 25.9 \\
\hline $\mathrm{LE}_{-} \mathrm{YT}_{\mathrm{n}}$ & $y=0.0054 x-2.1455$ & 0.4 & -2.0 \\
\hline LO-YT & $y=0.0296 x+10.387$ & 2.0 & 11.4 \\
\hline $\mathrm{LO} \mathrm{YT}_{\mathrm{x}}$ & $y=0.0287 x+25.353$ & 2.0 & 26.3 \\
\hline $\mathrm{LO}-\mathrm{YT}_{\mathrm{n}}$ & $\mathrm{y}=0.0331 \mathrm{x}-1.3454$ & 2.3 & -0.2 \\
\hline NG-YT & $y=0.0279 x+10.641$ & 1.9 & 11.6 \\
\hline
\end{tabular}




\begin{tabular}{|c|c|c|c|}
\hline Time series & Trend equation & $\Delta y\left({ }^{\circ} \mathbf{C}\right)$ & Average temperature $\left({ }^{\circ} \mathrm{C}\right)$ \\
\hline $\mathrm{NG} \mathrm{YT}_{\mathrm{x}}$ & $y=0.0272 x+24.042$ & 1.9 & 25.0 \\
\hline NG-YTn & $y=0.0281 x-1.9027$ & 1.9 & -1.0 \\
\hline NI-YT & $y=0.0168 x+11.263$ & 1.2 & 11.1 \\
\hline NI-YT $T_{x}$ & $y=0.0235 x+25.561$ & 1.6 & 26.4 \\
\hline NI-YT ${ }_{n}$ & $y=0.0185 x-1.0556$ & 1.3 & -0.3 \\
\hline NP-YT & $y=0.0405 x+8.1268$ & 2.8 & 9.5 \\
\hline$N P-Y_{x}$ & $y=0.0514 x+23.047$ & 3.5 & 24.9 \\
\hline $\mathrm{NP}-\mathrm{YT}_{\mathrm{n}}$ & $y=0.0413 x-4.8405$ & 2.8 & -3.4 \\
\hline PI-YT & $y=0.0305 x+9.9109$ & 2.1 & 11.0 \\
\hline $\mathrm{PI} \mathrm{YT}_{\mathrm{x}}$ & $y=0.0244 x+24.522$ & 2.1 & 25.4 \\
\hline $\mathrm{PI}-\mathrm{YT}_{\mathrm{n}}$ & $y=0.0198 x-2.9205$ & 1.4 & -2.2 \\
\hline PŽ-YT & $y=0.0207 x+8.8474$ & 1.4 & 9.6 \\
\hline$P Z ̌-Y T_{x}$ & $y=0.0232 x+24.139$ & 1.6 & 24.9 \\
\hline$P Z \check{Z}-Y_{n}$ & $y=0.0239 x-3.7112$ & 1.7 & -2.8 \\
\hline SJ-YT & $y=0.0207 x+5.8387$ & 1.4 & 6.6 \\
\hline$S J-Y T_{x}$ & $y=0.0371 x+19.309$ & 2.6 & 20.6 \\
\hline$S J-Y_{n}$ & $y=0.0243 x-8.8094$ & 1.7 & -8.0 \\
\hline SP-YT & $y=0.0191 x+10.818$ & 1.3 & 12.0 \\
\hline$S P-Y T_{x}$ & $y=0.0346 x+24.482$ & 2.4 & 25.7 \\
\hline $\mathrm{SP}_{-} \mathrm{YT}_{\mathrm{n}}$ & $\mathrm{y}=0.0171 \mathrm{x}-2.2929$ & 1.2 & -1.8 \\
\hline VA-YT & $y=0.0303 x+10.342$ & 2.1 & 11.4 \\
\hline$V A-Y_{x}$ & $y=0.0275 x+25.246$ & 2.0 & 26.2 \\
\hline$V A-Y_{n}$ & $\mathrm{y}=0.041 \mathrm{x}-2.4819$ & 2.8 & -1.1 \\
\hline VG-YT & $y=0.016 x+10.743$ & 1.1 & 11.4 \\
\hline $\mathrm{VG}-\mathrm{YT}_{\mathrm{x}}$ & $y=0.0261 x+23.804$ & 1.8 & 24.8 \\
\hline VG-YT ${ }_{n}$ & $y=-0.0062 x-0.9246$ & -0.4 & -1.1 \\
\hline VR-YT & $y=0.012 x+10.739$ & 0.8 & 11.2 \\
\hline$V R-Y T_{x}$ & $y=0.0369 x+23.108$ & 2.6 & 24.4 \\
\hline$V R-Y_{n}$ & $y=-0.0092 x-0.9409$ & -0.6 & -1.3 \\
\hline ZA-YT & $y=0.0172 x+10.227$ & 1.2 & 10.8 \\
\hline$Z A-Y_{x}$ & $y=0.0359 x+24.518$ & 2.5 & 25.8 \\
\hline $\mathrm{ZA}-\mathrm{YT}_{\mathrm{n}}$ & $y=0.0011 x-2.6094$ & 0.1 & -2.6 \\
\hline ZL-YT & $y=0.0211 x+6.8797$ & 1.5 & 7.6 \\
\hline $\mathrm{ZL}-\mathrm{YT}_{\mathrm{x}}$ & $y=0.0437 x+19.045$ & 3.0 & 20.5 \\
\hline $\mathrm{ZL}-\mathrm{YT}_{\mathrm{n}}$ & $y=0.0148 x-3.9099$ & 1.0 & -3.4 \\
\hline
\end{tabular}

Based on the magnitude of the trend $(\Delta y)$, the character of climate change can be presented, i.e., the average increase or decrease of observed climate variables. Generally speaking, the analyzed time series show an increase in average annual $(Y T)$, average maximum $\left(Y T_{x}\right)$ and average minimum $\left(Y T_{n}\right)$ air temperatures in Central Serbia. The highest average increase was recorded in the case of average maximum air temperatures (time series $\mathrm{KZZ}-\mathrm{YT}_{\mathrm{x}}$ records an 
average increase of $4.2{ }^{\circ} \mathrm{C}$ ). Weaker intensity of changes was recorded in two time series: $3.5^{\circ} \mathrm{C}\left(\mathrm{NP}-\mathrm{YT}_{\mathrm{x}}\right)$ and $3.0^{\circ} \mathrm{C}\left(\mathrm{JA}^{-} \mathrm{YT}_{\mathrm{n}}\right)$. The lowest increase in air temperature was recorded in the case of average minimum air temperatures (time series $\mathrm{ZA}-\mathrm{YT}_{\mathrm{n}}$ ). In this particular case, an average increase in air temperature of only $0.1^{\circ} \mathrm{C}$ was recorded. Similar results were observed in the time series DI-YT $\left(\Delta y\right.$ is $\left.0.2^{\circ} \mathrm{C}\right)$ and $\mathrm{JA}_{\mathrm{n}} \mathrm{YT}_{\mathrm{x}}\left(\Delta y\right.$ is $\left.0.2^{\circ} \mathrm{C}\right)$. In two time series, which refer to air temperatures $Y T_{n}\left(\mathrm{VR}-\mathrm{YT}_{\mathrm{n}}\right.$ and $\left.\mathrm{VG}-\mathrm{YT}_{\mathrm{n}}\right)$, a decrease in air temperature was recorded, with averages $-0.6{ }^{\circ} \mathrm{C}$ and $-0.4{ }^{\circ} \mathrm{C}$, respectively.

\subsection{Trend assessment}

The results obtained by applying the non-parametric MK trend test, which serves to assess the hypotheses, are described in more detail in Fig. 3. General conclusions can be summarized in the following statements: a) out of a total of 72 time series, a statistically significant positive trend was recorded in 61 time series (the hypothesis $H_{a}$ prevails, while the $p$ value is lower than the significance level $\alpha$ ). In these time series the risk percentage is very low and ranges from $0.01 \%$ to $5.00 \%$, which indicates that this statement should not be rejected; b) on the other hand, in the remaining 11 time series there is no trend (and in these cases the hypothesis $H_{o}$ prevails, while the $\mathrm{p}$ value is greater than the significance level $\alpha$ ). In these time series, the risk of rejecting this hypothesis is significantly higher and ranges from $5.00 \%$ to $95.46 \%$. In four time series, the risk of rejecting such a claim ranges from $5.00 \%$ to $10.00 \%$, which indicates that there is no trend. Also, in the next four time series, the risk of rejecting this hypothesis ranges from $10.00 \%$ to $50.00 \%$, which indicates a declining trend. In the last three time series, the value of risk ranges from $70.15 \%$ to $95.46 \%$, which indicates a growing trend and a possible transition to a positive trend.

In most of the analyzed cases, a positive equation trend is followed by a positive significant trend from MK test (Fig. 3). The third case shows two deviations, when the positive trend was not recognized by the MK test in Knjaževac, as well as the negative trend was not recognized in Veliko Gradište. According to the MK test in case of Vranje, a positive significant trend was recorded together with a negative equation trend. 
a)

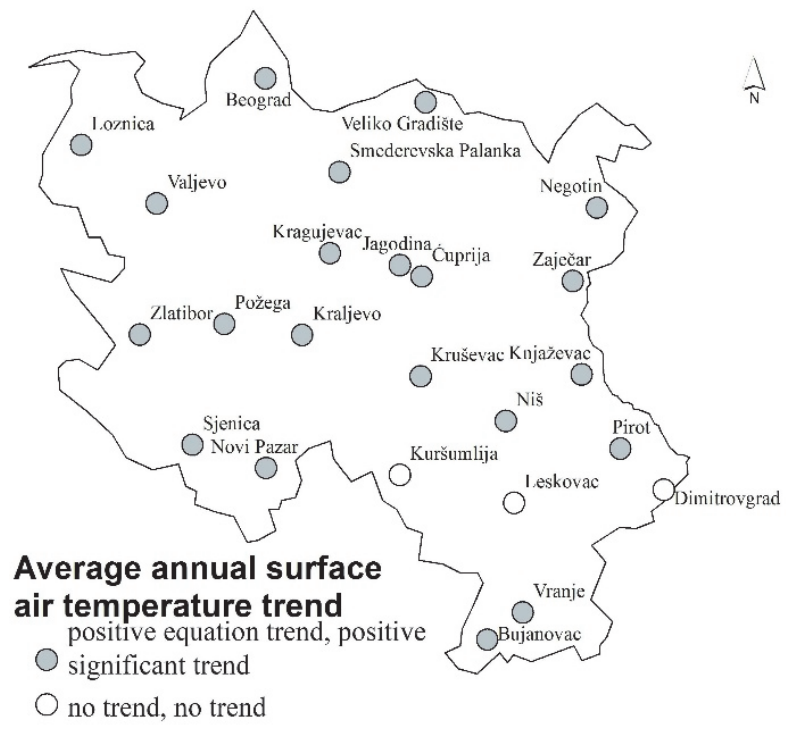

b)

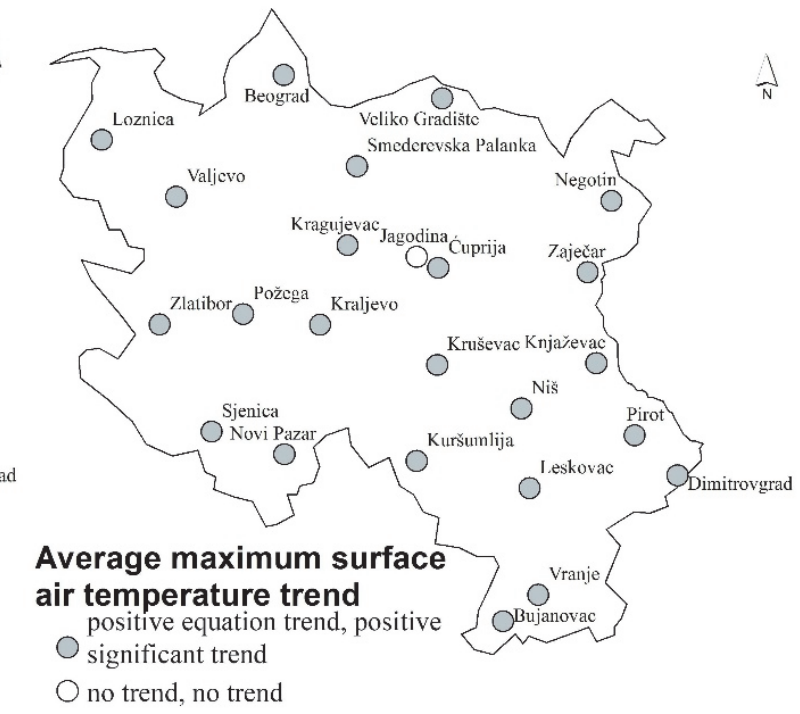

c)

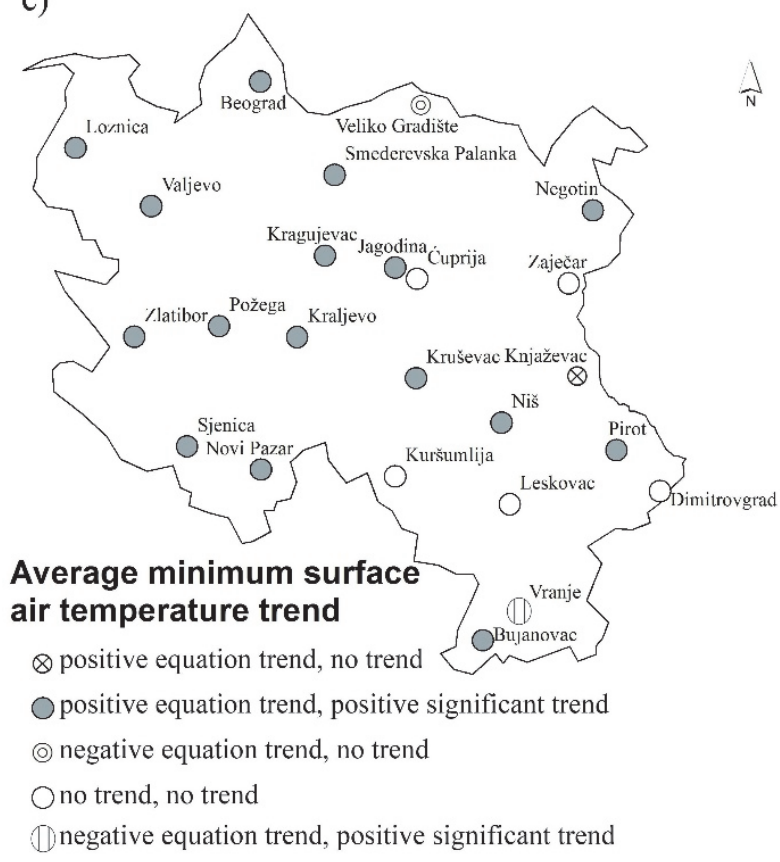

Fig. 3. The results of linear equation trends and MK test separated by a comma: a) average annual air temperature; b) average maximum air temperature; c) average minimum air temperature. 


\subsection{GIS numerical analysis}

The spatial distribution of average annual $(Y T)$, average maximum $\left(Y T_{x}\right)$ and average minimum $\left(Y T_{n}\right)$ air temperatures from 1949 to 2018 in Central Serbia is shown in more detail in Fig. 4.

a)

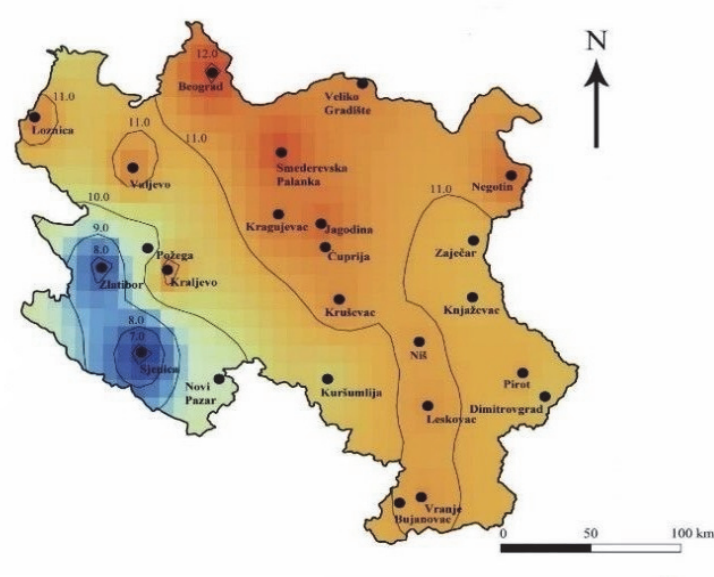

b)

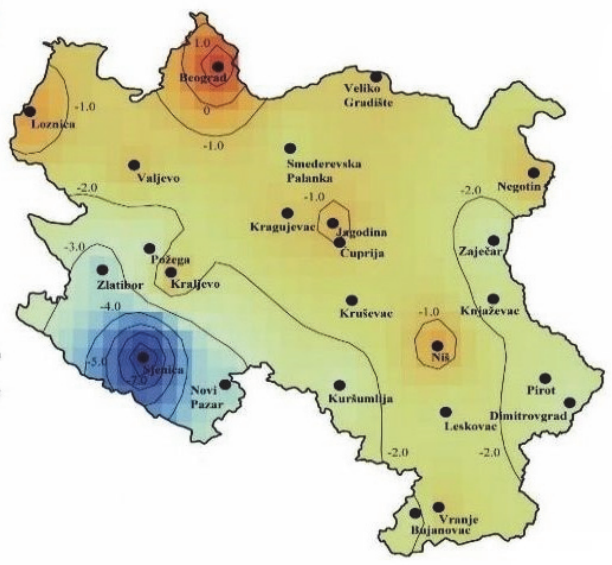

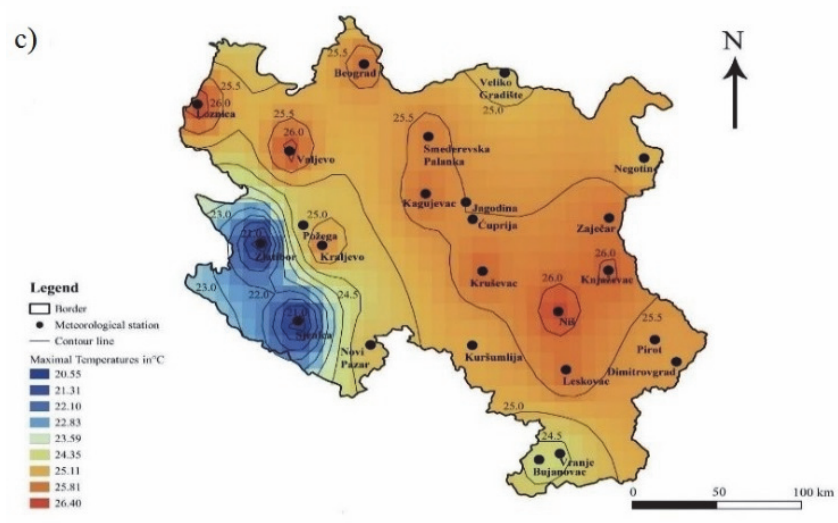

Fig. 4. Spatial distribution of a) average annual $(Y T)$, b) average maximum $\left(Y T_{x}\right)$, and c) average minimum $\left(Y T_{n}\right)$ air temperatures from 1949 to 2018 in Central Serbia.

Fig. 4 shows the distribution of average annual air temperatures (YT) in the analyzed area. Interregional differences in average air temperatures are caused by the influence of orography. Thus, the isotherms of $7^{\circ} \mathrm{C}$ and $8{ }^{\circ} \mathrm{C}$ dominate in the hilly and mountainous area of the southwestern part of Central Serbia. The meteorological station at Beograd limits the isotherm to $12{ }^{\circ} \mathrm{C}$, where the influence of the "urban heat island" is obvious. Thermal conditions in the central, eastern, and southern parts of the study area are limited by the $11{ }^{\circ} \mathrm{C}$ isotherm. 
The values of average maximum air temperatures $\left(Y T_{x}\right)$ from 1949 to 2018 are summarized in Fig. 4. The patterns of behavior of average maximum air temperatures are similar in relation to average air temperatures. The valley positions of cities such as Niš, Knjaževac, Loznica, and Valjevo are the cause of the high average maximum air temperature (isotherm of $26^{\circ} \mathrm{C}$ ). These thermal oases are also the "poles of heat" of the analyzed area. The thermal inequalities of Zlatibor and Sjenica are even more caused by terrain hypsometry (isotherms of only $21^{\circ} \mathrm{C}$ ).

In the spatial distribution of average minimum air temperatures $\left(Y T_{n}\right)$ from 1949 to 2018, significant differences can be noticed in relation to the previously analyzed climate variables (Fig. 4). The effect of the "city heat island" can be partly explained by the increase in the average minimum air temperature at the meteorological station at Beograd, as a macro-proportional variation that affects the local microclimate. Here, in addition to the impact of urbanization and the increase in the population of the urban area, the intense warming in the winter months, the impact of traffic and industry come to the fore (Unkašević, 1994). However, additional research is needed to correlate the relationship between these parameters and the average minimum air temperature. At most meteorological stations, in the case of average minimum air temperatures, isotherms from $-1.0{ }^{\circ} \mathrm{C}$ to $-2.0{ }^{\circ} \mathrm{C}$ dominate. The exceptions are, as in the case of average annual $(Y T)$ and average maximum air temperatures $\left(Y T_{x}\right)$, the meteorological stations Sjenica $\left(-7.0^{\circ} \mathrm{C}\right)$ and Zlatibor $\left(-4.0^{\circ} \mathrm{C}\right)$, which represent the "cold poles" in Central Serbia.

\section{Discussion}

From the above presented results it can be concluded that the increase of the air temperature is dominant in Central Serbia. Based on the trend magnitude in Table 2, the increase in the temperatures was in a wide range of values from $0.1{ }^{\circ} \mathrm{C}$ to $4.2^{\circ} \mathrm{C}$. However, in two time series related to the mean minimal air temperatures, the decreases from $-0.4{ }^{\circ} \mathrm{C}$ and $-0.6{ }^{\circ} \mathrm{C}$ were identified. This behavior of the air temperatures in Central Serbia resembles the warming in the Northern Hemisphere (Leroux, 2005). Warming is expected to be enhanced and accelerated in the high latitudes of the Northern Hemisphere (the so-called "Arctic amplification" effect). The rise in Arctic near-surface air temperatures has been twice as large as the global average in recent decades (Screen and Simmonds, 2010). Zheng and Wang (2019) identified the past two summers as very hot in the Northern Hemisphere. A combination of natural internal variabilities and global warming explains summer air temperature variations in the Northern Hemisphere.

It is difficult to find identical results in regions over the world, but there are some similarities. Türkes and Sümer (2004) detected increasing air 
temperatures in the western part of Turkey. Kousari and Asadi Zarch (2011) identified a significantly increasing trend for the minimum and mean temperatures while changes were not found for the maximum temperature in arid and semi-arid regions of Iran. In the mountainous part of Europe, the Swiss temperatures from 1959 to 2008 were analyzed (Ceppi et al., 2012). The authors summarized: a) all trends are positive and mostly significant with an annual average warming rate of $0.35{ }^{\circ} \mathrm{C} /$ decade $(\sim 1.6$ times as large as the northern hemispheric warming rate), b) altitude-dependent trends are found in autumn and early winter, where the trends are stronger at low altitudes $(<800 \mathrm{~m}$ asl), and in spring where slightly stronger trends are found at altitudes close to the snow line. In the wider Mediterranean region, increasing trends have also been recorded. In their paper, Gonzalez-Hidalgo et al. (2015) suggested that the warming rate in the Spanish mainland reached a maximum between 1970 and 1990, followed by a decrease in intensity in bothmaximum temperatures ( $T_{\max }$ ) and minimum temperatures $\left(T_{\min }\right)$ until the present. Furthermore, the decrease in the warming rate in $T_{\max }$ has been higher than in $T_{\min }$ for the last three decades; therefore, recent annual warming rates appears to depend more on $T_{\min }$ than on $T_{\max }$. Significant trends disappear from the middle of the 1980s at any temporal window length in both $T_{\max }$ and $T_{\min }$ at annual and seasonal scales except in spring $T_{\min }$. By analyzing data from 52 meteorological stations in Greece, a negative trend between 1960 and 1976 was found (Mamara et al., 2016). A statistically significant positive trend has been reported since the period from 1977 to 2004. In the Southern Levantine Basin, Tonbol et al. (2018) examined the mean annual variations. The results of the study revealed that 2010 was the hottest year in the region, while 2011 was the coolest. These conclusions are in agreement with the latest IPCC report (2018), in which the increase in the global temperature is not homogeneously distributed on the Earth surface. Similarly, in the near region, the temperature increase is dominant in Montenegro (Burić et al., 2014), Bosnia and Herzegovina (Trbić et al., 2017; Popov et al., 2018a, 2018b, 2019). In the territory of Serbia, in the region of Vojvodina (Gavrilov et al., 2015, 2016) and in Kosovo (Gavrilov et al., 2018), positive trends in air temperature were also observed. However, Radaković et al. (2018) did not notice any significant changes in the aridity trends over Central Serbia. Therefore, the dominant increase of air temperature is not in accordance with aridity trends in the same study area.

\section{Conclusion}

Based on the analyzed climate variables, certain conclusions can be drawn. In this paper, a total of 72 time series were analyzed using: a) trend equations, b) trend magnitude indicating the average increase or decrease in air temperature, c) MK non-parametric trend test, and d) GIS numerical analysis. Based on the 
trend equation and the trend magnitude, the highest average increase was recorded in the case of average maximum air temperatures $\left(4.2^{\circ} \mathrm{C}\right)$. The lowest increase in air temperature was recorded in the case of average minimum air temperatures $\left(0.1^{\circ} \mathrm{C}\right)$. In two time series related to the average minimum air temperatures (VR-YT $\mathrm{n}_{\mathrm{n}}$ and $\mathrm{VG}-\mathrm{YT}_{\mathrm{n}}$ ), a decrease in air temperature was recorded, which are $-0.6{ }^{\circ} \mathrm{C}$ and $-0.4{ }^{\circ} \mathrm{C}$, respectively. Using the $\mathrm{MK}$ trend test, the obtained results indicate that in 61 time series, a statistically significant positive trend was recorded in the analyzed parameters. On the other hand, there are no changes in 11 time series (there is no trend). The spatial distribution of isotherms in Central Serbia is in the following intervals: from $6.6^{\circ} \mathrm{C}$ to $12.1{ }^{\circ} \mathrm{C}$ for the average annual temperature, from $20.6^{\circ} \mathrm{C}$ to $26.4^{\circ} \mathrm{C}$ for the average maximum temperature, andfrom $1.6^{\circ} \mathrm{C}$ to $-7.9^{\circ} \mathrm{C}$ for the average minimum temperature. Thermal inequalities are caused by pronounced hypsometric differences between the analyzed meteorological stations. They lead to the effect of a vertical thermal gradient - an average decrease of $0.65^{\circ} \mathrm{C}$ in air temperature per $100 \mathrm{~m}$ altitude difference (Oliver, 2005). The presented climate dynamics of this area provide a solid basis for studying climate variations in the future, especially extreme climate events such as drought. Since the beginning of the 21 st century, Europe has experienced a series of extremely hot and dry summers (2003, 2010, 2013, 2015) (Fink et al., 2003; Laaha et al., 2017). Drought causes numerous socio-economic consequences followed by water deficit, and impacts on nature and agricultural resources. These are the reasons why it is necessary to take appropriate adaptive measures before the manifestation of worse climatic conditions (Bressers et al., 2016). Central Serbia, as a significant agricultural region of the Republic of Serbia, requires certain measures in order to mitigate the resulting climate change, as defined in the Report of the Republic of Serbia under the UN Framework Convention on Climate Change (Ministry of Environmental Protection, 2017). Prominent reasons create the need for further research into the problems of climate change in Central Serbia (analysis of parameters such as absolute temperature extremes, seasonal air temperatures, and precipitation).

Acnowledgements: This paper represents the result within the projects III43007 and III044006 funded by the Serbian Ministry of Education, Science and Technological Development.

\section{References}

Anđelković, G., 2007: Temperature conditions on July 2007 as extreme climatic phenomenon in Serbia. Bull. Serbian Geograph. Soc. 87., . 51-62. https://doi.org/10.2298/GSGD0702051A

Ahmad, I., Tang, D., Wang, F.T., Wang, M. and Wagan, B. 2015: Precipitation Trends over Time Using Mann-Kendall and Spearman's rho Tests in Swat River Basin, Pakistan. Adv. Meteorol., 2015, Article ID 431860. https://doi.org/10.1155/2015/431860

Alexandersson, H. 1986. A homogeneity test applied to precipitation data. J. Climatol. 6, 661-675. https://doi.org/10.1002/joc.3370060607 
Alexander, L.V., Zhang, X., Peterson, T.C., Caesar, J., and Gleason, B. 2006: Global observed changes in daily climate extremes of temperature and precipitation. J. Geophys. Res., 2006, 111, D05109. https://doi.org/10.1029/2005JD006290

Bajat, B., Blagojević, D., Kilibarda, M., Luković, J., and Tošić, I. 2015: Spatial Analysis of the Temperature Trends in Serbia during the Period 1961-2010. Theor. Appl. Climatol. 121, 289301. https://doi.org/10.1007/s00704-014-1243-7

Bačević, R.N, Vukoičić, Z.D., Nikolić, M., Janc, N., Milentijević, N., and Gavrilov B.M. 2017: Aridity in Kosovo and Metohija, Serbia. Carpathian J. Earth Environ. Sci. 12, 563-570.

Bačević, R.N., Pavlović, M., and Rašljanin, I. 2018: Trend Assessing Using Mann-Kendall's Test for Priština Meteorological Station Temperature and Precipitation Data, Kosovo and Metohija, Serbia. The University Thought - Publ. Nat. Sci. 8(2), 39-43. https://doi.org/10.5937/univtho8-19513

Bindoff, N.L., P.A. Stott, K.M. AchutaRao, M.R. Allen, N. Gillett, D. Gutzler, K. Hansingo, G. Hegerl, Y. Hu, S. Jain, I.I. Mokhov, J. Overland, J., Perlwitz, R. Sebbari, and X. Zhang, 2013: Detection and Attribution of Climate Change: from Global to Regional. In: Climate Change 2013: The Physical Science Basis. Contribution of Working Group I to the Fifth Assessment Report of the Intergovernmental Panel on Climate Change (eds. Stocker, T.F., D. Qin, G.-K. Plattner, M. Tignor, S.K. Allen, J. Boschung, A. Nauels, Y. Xia, V. Bex and P.M. Midgley). Cambridge University Press, Cambridge, United Kingdom and New York, NY, USA.

Blake, A., Arbache, S.J, Sinclair, T.M., and Teles, V. 2007: Tourism and poverity relief. Annal. Tourism Res, 35, 107-126. https://doi.org/10.1016/j.annals.2007.06.013

Burić, D., Luković, J., Ducić, V., Dragojlović, J., and Doderović, M. 2014: Recent trends in daily temperature extremes over southern Montenegro (1951-2010). Nat. Hazards Earth Syst. Sci. 14, 67-72. https://doi.org/10.5194/nhess-14-67-2014

Burić, D., Ducić, V., Mihajlović, J., Luković, J. and Dragojlović, J. 2015: Recent extreme air temperature changes in Montenegro. Bull. Serbian Geograph. Soc. 95(4), 53-66. https://doi.org/10.2298/GSGD140626002B

Burić, B.D., Dragojlović, M.J., Milenković, M., Popović, Z.Lj. and Doderović, M.M., 2018: Influence of variability of the East Atlantic Oscillation on the air temperature in Montenegro. Thermal Sci. 22(1B), 759-766. https://doi.org/10.2298/TSCI170710211B

Burić D., Dragojlović J., Penjišević-Sočanac I., Luković J. and Doderović M., 2019: Relationship Between Atmospheric Circulation and Temperature Extremes in Montenegro in the Period 1951-2010. In: (eds. Leal Filho W., Trbic G., Filipovic D.) Climate Change Adaptation in Eastern Europe. Climate Change Management. Springer, Cham. https://doi.org/10.1007/978-3-030-03383-5_3

Burn, D.H. and Hag Elnur, M.A. 2002: Detection of hydrologic trends and variability. J. Hydrol. 255, 107-122. https://doi.org/10.1016/S0022-1694(01)00514-5

Bressers, J. T.A., Bressers, N., and Larrue, C., 2016: Governance for Drought Resilience: Land and Water Drought Management in Europe. Springer. https://doi.org/10.1007/978-3-319-29671-5

Ceppi, P., Scherrer, S.C., Fischer, A.M. and Appenzeller, C. 2012: Revisiting Swiss temperature trends 1959-2008. Int. J. Climatol. 32, 203-213. https://doi.org/10.1002/joc.2260

$D u$, Q., Zhang, M., Wang, S., Che, C., Ma, R., and Ma, Z., 2019: Changes in air temperature over China in response to the recent global warming hiatus. J. Geograph. Sci. 29, 496-516. https://doi.org/10.1007/s11442-019-1612-3

Ducić, V. and Radovanović, M. 2005: Klima Srbije. Beograd: ZUNS.

ElNesr, M.N., Abu-Zreig, M.M., and Alazba, A.A. 2010. Temperature trends and distribution in the Arabian Peninsula. Amer. J. Environ. Sci. 6, 191-203. https://doi.org/10.3844/ajessp.2010.191.203

Fink, A.H., Brücher, T., Krüger, A., Leckebusch, G.C., Pinto, J.G., and Ulbrich, U. 2003: The 2003 European summer heatwaves and drought-synoptic diagnosis and impacts. Weather 59, 209216. https://doi.org/10.1256/wea.73.04

Gavrilov, M.B., Marković, S.B., Jarad, A. and Korać, V.M., 2015: The analysis of temperature trends in Vojvodina (Serbia) from 1949 to 2006. Thermal Sci. 19, 339-350.

https://doi.org/10.2298/TSCI150207062G 
Gavrilov, M.B., Tošić, I., Marković, S.B., Unkašević, M., and Petrović, P. 2016: The analysis of annual and seasonal temperature trends using the Mann-Kendall test in Vojvodina, Serbia. Idöjárás 122, 203-216.

Gavrilov, M.B., Marković, S.B., Janc, N., Nikolić, M., Valjarević, A., Komac, B., Zorn, M., Punišić, $M$. and Bačević, N., 2018: Assessing average annual air temperature trends using the MannKendall test in Kosovo. Acta geographica Slovenica, 58, 8-25. https://doi.org/10.3986/AGS.1309

Gavrilov, M.B., Lukić, T., Janc, N., Basarin, B., and Marković, S.B. 2019: Forestry Aridity Index in Vojvodina, North Serbia. Open Geosciences 11, 367-377. https://doi.org/10.1515/geo-20190029

Gocić, M. and Trajković, S., 2013: Analysis of changes in meteorological variables using Mann Kendall and Sen's slope estimator statistical tests in Serbia. Glob. Planet. Change 100, 172182. https://doi.org/10.1016/j.gloplacha.2012.10.014

Gocić, M. and Trajković, S. 2014a: Drought Characterisation Based on Water Surplus Variability Index. Water Res. Manage. 28, 3179-3191. https://doi.org/10.1007/s11269-014-0665-4

Gocić, M. and Trajković, S. 2014b: Spatiotemporal characteristics of drought in Serbia. J. Hydrology, 510, 110-123. https://doi.org/10.1016/j.jhydrol.2013.12.030

Gonzalez-Hidalgo, J.C., Peña-Angulo, D., Brunetti, M. and Cortesi, N., 2015: Recent trend in temperature evolution in Spanish mainland (1951-2010): from warming to hiatus. Int. J. Climatol. 36, 2405-2416. https://doi.org/10.1002/joc.4519

Hansen, J., Sato, M., Russell, G., and Kharecha, P. 2013: Climate sensitivity, sea level and atmospheric carbon dioxide. Philosophical transactions. Series A, Mathematical, physical, and engineering sciences, 371(2001), 20120294. https://doi.org/10.1098/rsta.2012.0294

Hrnjak, I., Lukić, T., Gavrilov, M.B., Marković, S.B., Unkašević, M. and Tošić, I. 2014. Aridity in Vojvodina, Serbia. Theor. Appl. Climatol. 115, 323-332. https://doi.org/10.1007/s00704-0130893-1

$I P C C$, 2018: Summary for Policymakers. In: Global Warming of $1.5^{\circ} \mathrm{C}$. An IPCC Special Report on the impacts of global warming of $1.5^{\circ} \mathrm{C}$ above pre-industrial levels and related global greenhouse gas emission pathways, in the context of strengthening the global response to the threat of climate change, sustainable development, and efforts to eradicate poverty [MassonDelmotte, V., P. Zhai, H.-O. Pörtner, D. Roberts, J. Skea, P.R. Shukla, A. Pirani, W. Moufouma-Okia, C. Péan, R. Pidcock, S. Connors, J.B.R. Matthews, Y. Chen, X. Zhou, M.I. Gomis, E. Lonnoy, T. Maycock, M. Tignor, \& T. Waterfield (eds.)]. In Press.

Karaburun, A., Demirci, A. and Kara, F. 2011: Analysis of spatially distributed annual, seasonal and monthly temperatures in Istanbul from 1975 to 2006. World Appl. Sci. J. 12, 1662-1675.

Karmeshu, N. 2012: Trend Detection in Annual Temperature \& Precipitation using the Mann Kendall Test - A Case Study to Assess Climate Change on Select States in the Northeastern United States. MSc Thesis, University of Pennsylvania. USA.

Kendall, M. 1938: A new measure of rank correlation. Biometrika 30, 81-89. https://doi.org/10.2307/2332226

Klein, T.A.M.G. and Können, G.P., 2003: Trends in indices of daily temperature and precipitation extremes in Europe, 1946-99. J. Climate 16, 3665-3680. https://doi.org/10.1175/1520-0442(2003)016<3665:TIIODT>2.0.CO;2

Kocsis, T., Kovács-Székely, I. and Anda, A., 2020: Homogeneity tests and non-parametric analyses of tendencies in precipitation time series in Keszthely, Western Hungary. Theor. Appl.Climatol. 139, 849-859. https://doi.org/10.1007/s00704-019-03014-4

Kousari, M.R. and Asadi Zarch, M.A., 2011: Minimum, maximum, and mean annual temperatures, relative humidity, and precipitation trends in arid and semi-arid regions of Iran. Arabian J. Geoscie. 4, 907-914. https://doi.org/10.1007/s12517-009-0113-6

Laaha, G., Gauster, T., Tallaksen, L. M., Vidal, J.-P., Stahl, K., Prudhomme, C., Heudorfer, B., Vlnas, R., Ionita, M., Van Lanen, H. A. J., Adler, M.-J., Caillouet, L., Delus, C., Fendekova, M., Gailliez, S., Hannaford, J., Kingston, D., Van Loon, A. F., Mediero, L., Osuch, M., Romanowicz, R., Sauquet, E., Stagge, J. H., and Wong, W. K. 2017: The European 2015 drought from a hydrological perspective. Hydrol. Earth Syst. Sci. 21, 3001-3024. https://doi.org/10.5194/hess-21-3001-2017 
Leroux, M. 2005: Global Warming - Myth or Reality? Berlin Heidelberg, Springer.

Lukovic J., Buric D., Ducic V., Doderovic M. and Milevski I., 2013: Assessment on Temperature Extremes in Montenegro. In: (eds. Helmis C., Nastos P.) Advances in Meteorology, Climatology and Atmospheric Physics. Springer Atmospheric Sciences. Springer, Berlin, Heidelberg. https://doi.org/10.1007/978-3-642-29172-2_82

Mamara, A., Argiriou, A.A., and Anadranistakis, M. 2016: Recent Trend Analysis of Mean Air Temperature in Greece Based on Homogenized Data. Theo. Appl. Climatol. 126, 543-573. https://doi.org/10.1007/s00704-015-1592-x

Mann, H.B., 1945: Non-parametric tests against trend. Econometrica, 13, 245-259. https://doi.org/10.2307/1907187

Milentijević, N., Dragojlović, J., Ristić, D., Cimbaljević, M., Demirović, D. and Valjarević, A., 2018: The assessment of aridity in Leskovac Basin, Serbia (1981-2010). J. Geograph. Inst. "Jovan Cvijić", 68, 249-264.

Ministry of Environmental Protection, 2017: Second National Communication of the Republic of Serbia under the United Nations Framework Convention on Climate Change. Ministry of Environmental Protection, Belgrade.

Milošević, D., Savić, S. and Žiberna, I., 2013: Analysis of the climate change in Slovenia: Fluctuations of meteorological parameters for the period 1961-2011 (Part I). Bull. Serbian Geograph. Soc. 93, 114. https://doi.org/10.2298/GSGD1301001M

Milošević, D., Savić, S., Stankov, U., Žiberna, I., Pantelić, M., Dolinaj, D., and Leščešen, I., 2017: Maximum temperatures over Slovenia and their relationship with atmospheric circulation patterns. Geografie, 122, 1-20. https://doi.org/10.37040/geografie2017122010001

Mudelsee, M., 2014: Climate Time Series Analysis: Classical Statistical and Bootstrap Methods, 2nd edition. Cham, Switzerland: Springer.

Mudelsee, M., 2019: Trend analysis of climate time series: A review of methods, Earth-Sci. Rev. 190, 310-322. https://doi.org/10.1016/j.earscirev.2018.12.005

Oliver, E. J., 2005. Temperature Distribution. In (Ed. E.J. Oliver), Encyclopedia of World Climatology, 711-716. Springer, Dordrecht, The Netherlands.

Popov, T., Gnjato, S. and Trbić, G., 2017: Trends in extreme temperatures indices in Bosnia and Herzegovina: A case study of Mostar. Herald 21, 107-132. https://doi.org/10.7251/HER2117107P

Popov, T., Gnjato, S. and Trbić, G., 2018a: Changes in temperature extremes in Bosnia and Herzegovina: A fixed tresholds-based index analysis. J. Geograph. Inst. "Jovan Cvijić" SASA, $68,17-33$. https://doi.org/10.2298/IJGI1801017P

Popov, T., Gnjato, S., Trbić, G., and Ivanišević, M., 2018b: Recent trends in extreme temperature indices in Bosnia and Herzegovina. Carpathian J. Earth Environ. Sci. 13, 211-224. https://doi.org/10.26471/cjees/2018/013/019

Popov, T., Gnjato, S. and Trbić, G., 2019: Changes in extreme temperature indices over the Peripannonian region of Bosnia and Herzegovina. Geografie 124, 19-40. https://doi.org/10.37040/geografie2019124010019

Putniković, S., Tošić, I., Lazić, L. and Pejanović, G., 2018: The influence of the large-scale circulation patterns on temperature in Serbia. Atmosph. Res. 213, 465-475. https://doi.org/10.1016/j.atmosres.2018.07.003

Radaković, G.M., Tošić, A.I., Bačević, R.N., Mlađan, D., Marković S.B., and Gavrilov M.B., 2018: The analysis of aridity in Central Serbia from 1949-2015. Theor. Appl. Climatol. 133, 887-898. https://doi.org/10.1007/s00704-017-2220-8

Radilović, S., Koračin, D., Denamiel, C., Belušić, D., Güttler, I. and Vilibić, I., 2020: Simulated and observed air temperature trends in the eastern Adriatic. Atmosph. Sci. Lett. 21, e951. https://doi.org/10.1002/asl.951

Radinović, Đ., 1981: Vreme i klima Jugoslavije. Beograd: IRO “Građevinska knjiga”. 
Rahman, M.A., Yunsheng, L., and Sultana, N., 2017: Analysis and prediction of rainfall trends over Bangladesh using Mann-Kendall, Spearman's rho tests and ARIMA model. Meteorol. Atmosph. Physics 129, 409-424. https://doi.org/10.1007/s00703-016-0479-4

Razavi, T., Switzman, H., Arain, A. and Coulibaly, P., 2016: Regional climate change trends and uncertainty analysis using extreme indices: A case study of Hamilton, Canada. Climate Risk Manage. 13, 43-63. https://doi.org/10.1016/j.crm.2016.06.002

RHSS, 2019: Meteorological Yearbook - Climatological Data (Meteorological Yearbook, http://www.hidmet.gov.rs/ciril/meteorologija/klimatologija_godisnjaci.php (accessed 30 February 2020).

Serra, C., Burgueño, A. and Lana, X. 2001: Analysis of maximum and minimum daily temperatures recorded at Fabra Observatory (Barcelona, NE Spain) in the period 1917-1998. Int. J. Climatol. 21, 617-636. https://doi.org/10.1002/joc.633

Screen, J.A. and Simmonds, I., 2010: The central role of diminishing sea ice in recent Arctic temperature amplification. Nature, 464(7293), 1334-1337. https://doi.org/10.1038/nature09051

Shadmani, M., Marofi, S. and Roknian, M., 2012: Trend Analysis in Reference Evapotranspiration Using Mann-Kendall and Spearman's Rho Tests in Arid Regions of Iran. Water Resour. Manage. 26, 211-224. https://doi.org/10.1007/s11269-011-9913-z

Tadić, L., Brleković, T., Hajdinger, A., and Španja, S., 2019: Analysis of the Inhomogeneous Effect of Different Meteorological Trends on Drought: An Example from Continental Croatia. Water, 11(12), 2625. https://doi.org/10.3390/w11122625

Tomazos, K. and Butler, R., 2009: Volunteer tourism: The new ecotourism? Anatolia: An International J. Tourism Hospitality Res. 20, 196-211. https://doi.org/10.1080/13032917.2009.10518904

Tonbol, K.M., El-Geziry, T.M., and Elbessa, M., 2018: Evaluation of Changes and Trends of Air Temperature within the Southern Levantine Basin. Weather 73, 60-66. https://doi.org/10.1002/wea.3186

Tošić, I., Zorn, M., Ortar, J., Unkašević, M., Gavrilov, M.B. and Marković, S.B., 2016: Annual and seasonal variability of precipitation and temperatures in Slovenia from 1961 to 2011. Atmosph. Res. 168, 220-233. https://doi.org/10.1016/j.atmosres.2015.09.014

Trajković S., Gocić M., Misic D. and Milanovic M., 2020: Spatio-Temporal Distribution of Hydrological and Meteorological Droughts in the South Morava Basin. In: (eds. Gocic M., Aronica G., Stavroulakis G. \& Trajković S.) Natural Risk Management and Engineering. Springer Tracts in Civil Engineering. Springer, Cham. https://doi.org/10.1007/978-3-03039391-5_11

Trbić, G., Popov, T. and Gnjato, S., 2017: Analysis of air temperature trends in Bosnia and Herzegovina. Geographica Pannonica, 21, 68-84. https://doi.org/10.5937/GeoPan1702068T

Türkes, M. and Sümer, U.M. 2004. Spatial and temporal patterns of trends and variability in diurnal temperature ranges of Turkey. Theor. Appl. Climatol. 77, 195-227. https://doi.org/10.1007/s00704-003-0024-5

Unkašević, M. 1994. Klima Beograda. Beograd: Naučna knjiga. (on Serbian)

Unkašević, M. and Tošić, I. 2013. Trends in temperature indices over Serbia: relationships to largescale circulation patterns. Int. J. Climatol. 33, 3152-3161. https://doi.org/10.1002/joc.3652

Valjarević, A., Djekić, T., Stevanović, V., Ivanović, R. and Jandziković, B., 2018: GIS numerical and remote sensing analyses of forest changes in the Toplica region for the period of 1953-2013. Applied Geography 92, 131-139. https://doi.org/10.1016/j.apgeog.2018.01.016

Vukoičić, Z.D., Milosavljević, A.S., Penjišević, T.I., Bačević, R.N., Nikolić, M., Ivanović, D.R. and Jandziković, M.B., 2018: Spatial analysis of temperature and its impact on the sustainable development of mountain in Central and Western Serbia. Idojjárás 122, 259-283. https://doi.org/10.28974/idojaras.2018.3.3

Zeleñáková, M., Purcz, P., Blištan, P., Vranayová, Z., Hlavatá, H., Diaconu, D.C. and Portela, M.M., 2018: Trends in Precipitation and Temperatures in Eastern Slovakia (1962-2014). Water, 10(6), p. 727. https://doi.org/10.3390/w10060727

Zheng, J. and Wang, C. 2019. Hot summers in the Northern Hemisphere. Geophysical Research Letters, 46, pp. 10891-10900. https://doi.org/10.1029/2019GL084219 
Wang, C., Puhan, M.A. and Furrer, R. 2018. Generalized spatial fusion model framework for joint analysis of point and areal data. Spatial Statistics 23, 72-90.

https://doi.org/10.1016/j.spasta.2017.11.006

Wibig, J. and Glowicki, B. 2002. Trends of minimum and maximum temperature in Poland. Climate Res. 20, 123-133. https://doi.org/10.3354/cr020123

$W M O, 2019$. Statement on the State of the Global Climate in 2018. WMO-No. 1233. World Meteorological Organization. Geneva, Switzerland.

XLSTAT, https://www.xlstat.com/en/ (accessed 10 March 2020). 